\title{
Nasionalisme Eropa dan Pengaruhnya Pada Lagu Seriosa di Indonesia
}

\author{
Ayu Tresna Yunita ${ }^{1}$ \\ Jurusan Musik, Fakultas Seni Pertunjukan, Institut Seni Indonesia Yogyakarta
}

\begin{abstract}
ABSTRAK
Gerakan nasionalisme berkembang di Eropa pada tahun 1830 dan menyebar ke berbagai negara di dunia termasuk di Indonesia. Gerakan nasionalisme Eropa pada perkembangannya memberi pengaruh yang besar terhadap perkembangan nasionalisme di kawasan Asia-Afrika khususnya di Indonesia dan perkembangan dalam sejarah musik. Gerakan nasionalisme dalam musik diawali di Rusia lalu kemudian diikuti gerakan nasionalisme di negaranegara Skadinavia, Spanyol, Italia, Hongaria, Inggris dan Amerika Serikat. Nasionalisme Eropa mempengaruhi beberapa komponis dalam menciptakan karya musiknya. Mereka memasukkan unsur-unsur melodi dan syair yang sesuai dengan musik rakyat dan yang sudah dikenal oleh masyarakat mereka. Di Indonesia, nasionalisme membuat para komponis Indonesia menciptakan lagu dengan tujuan mengobarkan semangat berjuang untuk melepaskan diri dari penjajah. Beberapa komponis Indonesia pada waktu jaman itu antara lain, W.R. Supratman, Kusbini, Ismail Marzuki dan Cornel Simanjuntak. Lagu seriosa yang diciptakan para komponis Indonesia mempunyai peranan yang besar terhadap perjuangan mencapai kemerdekaan. Lagu-lagu seriosa yang diciptakan dengan menggunakan ilmu-ilmu musik dari Barat seperti tangganada diatonis, harmoni, struktur bentuk lagu, ritmes dan lain sebagainya merupakan hasil pengaruh musikal dari Barat.
\end{abstract}

Kata kunci: Nasionalisme, pengaruh musikal, lagu seriosa

\section{ABSTRACT}

Nasionalism in Europ and Its Impact on Indonesian Seriosa Song. The growing of nationalism movements in Europe in 1830 had spread out to all over the world, as well as in Indonesia. It gave considerable influence on the development of nationalism in Asia and Africa, especially in Indonesia, in term of the development in the history of music. The nationalism movement in music began in Russia and then was followed by the movement of nationalism in Scandinavian countries, Spain, Italy, Hungary, the United Kingdom and the United States. European nationalism has affected several composers in creating their music as they incorporate elements of melody and lyric in accordance with folk music which they have been familiar with. In Indonesia, nationalism made Indonesian composers created songs as an expression of their spirit against the Dutch colonial government. Some of Indonesian composers at that time, among others, were WR Supratman, Kusbini, Ismail Marzuki and Cornel Simanjuntak. Seriosa Song composed by Indonesian composers who had an important role to fight for the Indonesian independence. Seriosa songs which are created by using western musical's standard as diatonic scales, harmony, the structure of a song form, rhyme, and so forth can be said as a result of the western musical infuences.

Keywords: Nationalism, musical infuences, seriosa song

\section{Pendahuluan}

Perang Dunia I dan Revolusi Perancis yang terjadi pada akhir abad ke-18 mempunyai pengaruh yang besar bagi berkembangnya gagasan nasionalisme di Eropa. Secara etimologis nasionalisme berasal dari Bahasa Inggris yaitu nation yang berarti bangsa. Di Eropa paham nasionalisme dipicu oleh berbagai peristiwa. Peristiwa tersebut antara lain terjadinya revolusi Perancis, revolusi industri di Inggris dan juga Revolusi Amerika. Secara garis besar dapat diartikan bahwa nasionalisme sebagai suatu paham atau kesadaran rasa kebangsaan sebagai bangsa, yang didasarkan atas adanya rasa cinta kepada tanah air dan bangsa dalam mencapai, mempertahankan mengabadikan identitas dan integrasi kekuatan bangsanya (Kohn, 1984:11).

Perkembangan sejarah musik pada abad ke19 dan awal abad ke-20 adalah salah satu jaman yang mengalami banyak perubahan. Pada masa itu aliran romantik di Jerman dan di Perancis mulai berakhir, yang sekaligus menjadi suatu transformasi dari gaya romantik menjadi suatu bahasa musik yang baru, khususnya di negara Jerman. Selama ini Jerman dan Austria menjadi pusat musik Barat sejak masa Joseph Haydn dan

1 Alamat korespondensi: Prodi Musik ISI Yogyakarta. Jalan Parangtritis KM. 6,5 Sewon, Yogyakarta. E-mail: ayutresnayunita@ yahoo.com. HP: 08164260869. 
Wolfgang Amadeus Mozart. Kemudian pendapat tersebut mulai berubah karena disebabkan oleh dua hal. Hal yang pertama adalah kebangkitan musik Perancis, sedangkan hal yang kedua adalah perkembangan gerakan nasionalisme dalam musik.

Pada abad ke-19 muncul suatu kebangkitan dan kesadaran identitas musik nasional diantara bangsa-bangsa di Eropa. Para komponis mulai memasukkan unsur-unsur dari musik rakyat tradisional setempat. Hal ini disebabkan karena melodi-melodi tersebut cocok dengan irama dan intonasi dengan bahasa mereka. Melodi-melodi tersebut sudah dikenal oleh bangsa mereka sendiri sehingga musik mereka menjadi bisa lebih diterima oleh masyarakat dan mereka dapat menciptakan musik yang lebih khas, yang tidak meniru gaya Jerman atau Italia seperti jaman silam (McNeill, 2003: 215). Pengaruh musik Jerman ini juga terasa di Inggris dan Amerika Serikat sehingga membangkitkan suatu reaksi yang bersifat nasionalis. Gerakan nasionalisme di Eropa kemudian mulai meyebar ke seluruh dunia termasuk di Asia-Afrika.

Di Indonesia pergerakan nasional merupakan bagian dari sejarah Indonesia pada abad ke-20, yang ditandai dengan munculnya nasionalisme Indonesia. Beragamnya penyebutan istilah tentang Sejarah Pergerakan Nasional ini pada dasarnya mempunyaimaknayangsamayaitumenunjukpada nasionalisme. Dengan kata lain sejarah pergerakan nasional merupakan sejarah Indonesia dimana mulai muncul rasa nasionalisme bangsa Indonesia atas penindasan dan penjajahan Belanda. Sejarah pergerakan nasional diawali dengan lahirnya organisasi pertama Budi Utomo pada tahun 1908 sampai masa proklamasi Kemerdekaan Indonesia pada tahun 1945. Lahirnya Budi Utomo sebagai pelopor terbentuknya organisasi-organisasi di Indonesia seperti Sarekat islam (1912), Indische Partij (1912) dan juga organisasi-organisasi wanita pun juga ikut mengisi perjalanan sejarah pergerakan nasional. Taman Siswa yang didirikan oleh Ki Hajar Dewantara pada tanggal 3 juli 1922 merupakan pengajaran pendidikan dalam perguruan untuk mendidik putra putri Bangsa Indonesia. Dengan berdirinya Taman Siswa yang mendidik angkatan muda dalam jiwa kebangsaan Indonesia merupakan dasar untuk meninggikan derajat rakyat.
Bentuk perjuangan kemerdekaan bangsa Indonesia pada waktu itu masih bersifat kedaerahan. Munculnya organisasi-organisasi pemuda yang didirikan pemuda pelajar seperti organisasi Budi Utomo, Sarekat Islam, Taman Siswa dan lain sebagainya merupakan tempat dalam bentuk organisasi yang mempersatukan para pemuda Indonesia untuk bersatu membebaskan diri dari penjajah (Marwati Djoened dan Nugroho Notosusanto, 1984: 177).

Komponis-komponis Indonesia pada waktu itu juga ikut berjuang melawan penjajah dengan cara melalui lagu-lagu perjuangan yang mereka ciptakan. Banyak sekali pesan terselubung dalam syair-syair lagu perjuangan, antara lain meningkatkan semangat perjuangan, cinta kepada tanah air dan keinginan untuk menjadi bangsa yang merdeka dan terlepas dari penjajahan. Lagu perjuangan Indonesia disebut sebagai musik nasional yaitu musik yang diciptakan untuk tujuan nasional yang dapat mempersatukan bangsa dan tidak terdapat unsur etnis kedaerahan.

Lagu perjuangan merupakan musik nasional Indonesia yang bertemakan semangat perjuangan dan persatuan. Disebut sebagai musik nasional karena lagu perjuangan diciptakan dengan memakai aturan-aturan musik Barat seperti penggunaan tangganada diatonis, harmoni, ritme dan tidak berciri etnis. Secara umum pengertian lagu perjuangan Indonesia adalah kemampuan daya upaya yang timbul melalui peranan kesenian didalam gerakan peristiwa sejarah kemerdekaan Indonesia yang membangkitkan gelora semangat perjuangan dalam usaha melepaskan diri dari penindasan dan penjajahan di seluruh Indonesia (Sri Martono, 1953: 668). Kegunaan lagu-lagu perjuangan adalah memotivasi semangat rakyat Indonesia menghadapi tantangan dan hambatan untuk mencapai kemerdekaan.

Sejarah merupakan ilmu yang sangat membantu mendiskripsikan pengaruh kebangkitan nasionalisme Eropa terhadap perkembangan lagu seriosa di Indonesia. Ilmu sejarah digunakan untuk mengungkapkan latar belakang peristiwaperistiwa nasionalisme di Eropa, nasionalisme di Indonesia serta pengaruhnya terhadap lagu seriosa sebagai salah satu sarana para seniman untuk ikut berjuang mendapatkan kemerdekaan. Penulisan sejarah menggunakan teori dan metodologi. Penjelasan masalah teori dan metodologi sebagai 
bagian dari ilmu pokok sejarah. Teori dan metodologi ilmu sejarah mulai digunakan ketika penulisan sejarah tidak semata-mata mempunyai tujuan menceritakan kejadian, tetapi bertujuan menerangkan kejadian tersebut dengan mengkaji sebab-sebabnya, kondisi lingkungannya, konteks sosial kulturalnya. Pada intinya akan dibahas secara mendalam dengan menganalisis tentang faktor-faktor kausal, kondisional, kontekstual serta unsur-unsur yang merupakan komponen dan eksponen dari proses sejarah yang dikaji (Sartono Kartodirdjo, 1993).

Penelitian ini menggunakan metode penelitian deskriptif kualitatif dengan menggunakan pendekatan multi disiplin yaitu pendekatan historis dan musikologis. Penelitian kualitatif menurut Bogdan dan Taylor yaitu untuk menghasilkan data deskriptif berupa kata-kata tertulis atau lisan dari orang-orang dan perilaku yang dapat diamati. Pendekatan ini diarahkan pada latar dan individu tersebut secara holistik atau utuh. Jadi dalam hal ini tidak boleh mengisolasikan individu atau organisasi ke dalam variabel atau hipotesis, tetapi perlu memandangnya sebagai bagian dari suatu keutuhan (Moleong, 2004: 4).

Tahap yang pertama yang dilakukan yaitu pengumpulan data, kemudian menganalisis data lalu menulis kesimpulan. Terdapat berbagai macam sumber data kualitatif yang dipergunakan yaitu (1) sumber tertulis; (2) sumber lisan; (3) artefak; (4) peninggalan sejarah; dan (5) rekaman (R.M. Soedarsono, 2001: 129). Setelah semua data terkumpul maka berikutnya adalah menyusun laporan dan menulis hasil penelitian dalam bentuk karya tulis.

Pendekatan musikologis digunakan untuk mengkaji struktur musikal secara analisis struktural dari musik. musikologi meliputi akustik, fisiologi suara, pendengaran, psikologi estetik, apresiasi musikal, pendidikan musik, termasuk folksong dan folk dance, rime dan metrik, modus dan tangganada, prinsip, dan pengembangan alat musik, orkestrasi, bentuk, teori-teori dan harmoni, sejarah musik, bibliografi dan terminologi musik (Scholes, 1978).

\section{Paham Nasionalisme di Eropa dan di Indonesia}

Di Eropa paham nasionalisme dipicu oleh berbagai peristiwa. Peristiwa tersebut antara lain terjadinya revolusi Perancis, revolusi industri di Inggris dan juga revolusi Amerika. Dalam dimensi politik nasionalisme merupakan ideologi yang menyakini bahwa kesetiaan individu harus diserahkan kepada negara kebangsaan, yaitu suatu negara yang penduduknya memiliki hak dan kewajiban yang sama serta mau mengikatkan dirinya dalam suatu Negara (Kohn, 1984: 11).

Pada dasarnya semangat nasionalisme di satu sisi mampu mewujudkan kehidupan negara dengan semangat kebangsaan yang tinggi, namun di sisi lain semangat nasionalisme yang dilandasi sikap berlebihan menjadi salah satu faktor pendorong lahirnya semangat kolonialisme yang merugikan bangsa-bangsa. Nasionalisme berasal dari bahasa Inggris nation, dari bahasa latin natio yang berarti kelahiran suku bangsa, terutama bagi masyarakat yang sudah berkembang, sehingga mempunyai kesamaan sejarah, tradisi, dan kebudayaan bahasa dan biasanya disertai wilayahnya. Dengan adanya semangat nasionalisme menyebabkan timbulnya rasa kesadaran dan kesetiaan dalam anggota masyarakat untuk hidup bersatu dalam suatu negara yang merdeka.

Pelopor dan penganjur bagi tumbuh dan berkembangnya pemikiran nasionalisme tidak hanya kalangan politikus atau negarawan, tetapi juga dikembangkan oleh para ilmuwan dan para budayawan. Sebagai contoh pelopor pemikiran nasionalisme modern Eropa Barat dikenal seperti John Locke, J.J. Rousseu, Johan Gottfried Herder, dan lain-lain. Kedudukan mereka sebagai tokoh mempunyai pandangan yang dapat disimpulkan bahwa sikap pribadi yang terkandung pada diri seorang nasionalis tujuan utamanya adalah memperjuangkan bangsa, bukan untuk kepentingan pribadi atau golongan. Seiring perjalanan karier dan prestasinya sebagai figur masyarakat, seorang tokoh yang memiliki pengaruh serta kekuasaan, merupakan penjelmaan aspirasi seluruh rakyat serta menghilangkan keinginannya demi kepentingan bersama. Pada perkembangan berikutnya, kita dapat melihat bahwa melalui nasionalisme ini pula bangsabangsa terjajah seperti Indonesia dapat bangkit menentang dan melepaskan diri dari penjajah.

Pergerakan Nasional merupakan bagian dari Sejarah Nasional Indonesia pada abad ke-20 yang ditandai dengan munculnya nasionalisme di Indonesia. Nasionalisme adalah paham atau 
ajaran untuk mencintai bangsa dan negara sendiri. Kesadaran keanggotaan di suatu bangsa yang secara potensial atau aktual bersama-sama mencapai, mempertahankan, dan mengabadikan identitas, integritas, kemakmuran dan kekuatan bangsa itu (Kamus Besar Bahasa Indonesia, 2004: 775).

Nasionalisme di Indonesia adalah kualitas kejiwaan yang didasarkan pada kesadaran nasional yang mempunyai daya pemersatu seluruh bangsa untuk hidup bersama dan bekerjasama berdasarkan atas harga diri yang timbul dari masyarakat kebudayaan Indonesia. Nasionalisme Indonesia lahir bersamaan dengan tumbuhnya keinginan untuk membentuk negara nasional Indonesia. Kesadaran nasional ini merupakan kekuatan yang sangat menentukan bagi terwujudnya negarabangsa. Negara-bangsa itu tidak saja merupakan organisasi sosial politik, tetapi juga sebuah kerangka yang sangat diperlukan bagi semua aktivitas sosial, ekonomi, dan kebudayaan. Nasionalisme dan negara-bangsa Indonesia berkembang melelui proses sejarah yang panjang.

Politik Etis atau Politik Etika yang dikeluarkan Belanda bertujuan untuk meningkatkan taraf kesejahteraan dan pendidikan penduduk pribumi, hal ini disambut baik oleh masyarakat kebanyakan atau jelata (Marbangun Hardjowirogo, 1983: 144). Pelaksanaan tentang peningkatan taraf kesejahteraan bagi penduduk pribumi ternyata tidak terlaksana, hanya penduduk golongan bangsawan yang mendapat kesempatan memperoleh pendidikan. Politik etis memberikan kesempatan kepada para pemuda bangsa Indonesia mendapatkan pendidikan di sekolah-sekolah formal yang didirikan oleh bangsa Belanda di Indonesia. Dengan terbukanya kesempatan memperoleh pendidikan tersebut, melahirkan kaum cendekiawan dan pemuda terpelajar Indonesia. Kaum cendekiawan dan pemuda pelajar inilah yang mencetuskan gagasan nasionalisme untuk membebaskan diri dari kaum penjajah Belanda.

Terbentuknya Budi Utomo pada tanggal 20 Mei 1908, telah menciptakan langkah-langkah baru untuk mencapai kemerdekaan. Rakyat mulai sadar bahwa mereka mempunyai kewajiban untuk memerdekakan negaranya, terutama para pemimpin, para cerdik pandai nampak adanya keberanian untuk melawan penjajah (Eryono dkk., 1985: 35). Kemudian di Yogyakarta juga mulai muncul organisasi-organisasi yang dibentuk oleh kaum terpelajar dan berpendidikan. Salah satunya adalah Perguruan Tinggi Taman Siswa yang didirikan oleh Bapak R.M. Suwardi Suryaningrat atau yang lebih dikenal dengan nama Ki Hajar Dewantara. Lewat perguruan inilah anak-anak kita terdidik menjadi pemimpin-pemimpin bangsa.

Membicarakan komponis pada jaman nasionalisme di Indonesia sudah pasti karya-karya lagu yang mereka ciptakan berisi tentang semangat berjuang melawan penjajah dan cinta tanah air dan bangsa. Hal tersebut dikarenakan situasi politik bangsa Indonesia pada waktu itu, yang akhirnya mempengaruhi para komponis pada saat menciptakan lagu. Lagu-lagu perjuangan banyak diciptakan pada jaman nasionalisme di Indonesia. Jenis lagu perjuangan tersebut berbentuk Aubade, Mars, Hymne, Keroncong, Seriosa dan Pop.

Lagu-lagu seriosa merupakan pengaruh musikal dari Barat, yaitu pengaruh lied dari Jerman yang merupakan komposisi untuk vokal solo (tunggal) dan iringan piano. Penjelasan tentang lied (artsong atau sastra lagu) adalah sebuah komposisi yang diperuntukkan bagi vokal solo dan iringan piano. Secara konsep musikal, komposer menghadirkan musik iringan yang menjadi bagian yang penting dan berfungsi sebagai pasangan bagi melodi vocal (Kamien, 1988: 306). Hal tersebut menjadi ciri khas dari lagu seni bahwa antara lirik, melodi dan iringan diciptakan dalam suatu jalinan yang saling mengisi. Seperti yang ditegaskan oleh Roger Kamien bahwa puisi dan musik sudah terjalin dengan erat dalam lagu seni (Kamien, 1988: 37).

Pada jaman romantik sekitar tahun 1820 di Jerman, lagu seni berkembang pesat, puisi dan musik sudah terjalin dengan erat. Bentuk lagu seni ini mengalami perkembangan yang pesat bersamaan dengan munculnya beragam puisi romantik diawal abad ke-19. Lied merupakan komposisi yang menyatukan puisi dan musik ke dalam satu bentuk karya musik. Sehingga secara hubungan musikal, unsur lirik, melodi dan piano menjadi satu kesatuan. Para penulis Lied terbaik pada jaman tersebut antara lain adalah Franz Schubert, Robert Schuman dan Johannes Brahms. Sedangkan para penyair yang terkenal yaitu Johan Wolfgang Von Goethe (1749-1832) dan Heinrich Heine (1797-1856) (Kamien, 1988: 307). Lied karya komponis Franz Schubert antara 
lain An Die Musik, Die Post, Heidenröslein dan Schwanengesang.

Bentuk lagu lied Jerman terdiri dari tiga bentuk yaitu bentuk strophic, through-composed dan song cycle. Penjelasan tentang bentuk strophic adalah untuk memaknai suatu lagu yang terdiri dari semua bait lirik lagu, dinyanyikan dengan melodi dan iringan yang sama. Strophic merupakan suatu istilah untuk lagu yang menerapkan semua bait di dalam teks, dinyanyikan dengan melodi dan iringan yang sama. Hal ini berlainan dengan seni trough composed yang setiap baitnya mempunyai melodi dan iringan baru sesuai dengan makna yang terkandung di dalam lirik lagu pada tiaptiap bait (Tilmouth, 1984: XVII, 272). Dalam hal ini jika seorang komponis menciptakan lagu menggunakan bentuk strophic akan mengulang musik yang sama untuk tiap bait puisi (Kamien, 1988: 307). Ini juga dapat diartikan dengan penataan musikal dari sebuah naskah berbait yang menggunakan pengulangan lagu yang sama untuk semua bait (Fortune, 1969: 810). Contoh lied Jerman yang berbentuk strophic adalah lagu $A n$ Die Musik, Heidenröslein karya Franz Schubert.

Bentuk lagu through-composed diartikan secara umum yaitu suatu susunan lagu yang memberikan melodi dan iringan di setiap bait berbeda. Perbedaan tersebut di sesuaikan dengan makna yang terkandung di dalam lirik lagu sehingga suatu melodi hanya diperuntukkan pada satu bait lirik. Contoh lied Jerman yang berbentuk throughcomposed adalah Die Post karya Franz Schubert.

Song cycle merupakan susunan bentuk musik vokal yang terdiri dari beberapa bait lirik lagu baik solo maupun ansambel, yang masing-masing bait dikomposisikan menjadi satu lagu utuh, sehingga dalam suatu song cycle terdapat beberapa lagu sesuai dengan jumlah bait puisi yang ada. Kesatuan rasa musikal dari keseluruhan lagu diikat oleh alur cerita pada tema puisi tersebut (Peake, 1984: XVII, 521). Contoh Lied berbentuk cycle song adalah Die Shone Mullerin, Die Winterreise, Schwanengesang

Para komponis Indonesia mulai mengenal tangganada diatonis lewat lembaga formal maupun otodidak. Mereka mempelajari sistem musik Barat mulai dari harmoni, notasi musik balok, ritmis, irama, aransemen dan lain sebagainya melalui pendidikan di sekolah-sekolah. Para komponis juga mendapatkan kesempatan mempelajari musik Barat melalui kegiatan bermain musik bersama dalam bentuk orkes dan ansambel musik seperti pada saat mengisi siaran orkes-orkes di radio maupun bermain secara langsung di tempattempat hiburan.

Awal pembentukan musiknasionalterjadiketika para pemuda Indonesia mempunyai keinginan membebaskan diri dari kaum penjajah Belanda serta keinginan untuk menciptakan Kebudayaan Nasional yang tidak bersifat kedaerahan. Gerakan yang terjadi pada tahun 1920-an di bidang musik mengarah pada upaya untuk menciptakan musik yang tidak menonjolkan budaya daerah masingmasing atau yang berciri etnis. Keinginan tersebut merupakan usaha para pemuda bangsa yang ingin menciptakan musik yang dapat mempersatukan seluruh pemuda dalam satu kesatuan melalui musik nasional Indonesia.

\section{Lagu-Lagu Seriosa di Indonesia}

Di Indonesia lagu seriosa adalah lagu komposisi untuk musik vokal Indonesia, dan sebagai pengaruh musikal dari lied yang berasal dari Jerman. Lagu seriosa mulai berkembang di Indonesia pada tahun 1930-an yang dipelopori oleh Cornel Simanjuntak. Lagu seriosa juga merupakan bentuk musik yang merupakan kesatuan dari lirik, melodi, dan iringan piano. Lagu seriosa mengambil syair puisi sebagai lirik dalam lagu, seperti puisi dari W.S. Rendra, Chairil Anwar, Sanusi Pane dan lain sebagainya.

Lagu seriosa masuk ke dalam kelompok serius musik disebabkan karena lagu seriosa sebagai jenis musik yang dianggap memiliki mutu artistik tinggi. Lagu seriosa diciptakan dengan teknik musikal yang menggunakan teknik-teknik musik Barat antara lain tentang tangganada yang digunakan, pengucapan artikulasi harus tepat, intonasi untuk menyanyikan nada-nada yang tertulis juga harus tepat. Penyanyi seriosa harus menguasai teknik bernyanyi klasik Barat, sehingga dapat menyanyikan sesuai dengan teknik musik Barat tetapi tidak boleh dalam pembawaannya kemudian menjadi kaku (Harmunah, S.Mus. dalam wawancara tanggal 3 Agustus 2012). Bagi pendengar dan penikmat lagu seriosa dituntut adanya persyaratan seperti konsentrasi, pengalaman mendengar, dan pengetahuan dasardasar musik Barat umumnya. Pembuatan dan penyajian lagu seriosa dilakukan seperti jenis 
klasik, khususnya jenis lied dan lazimnya tampil dalam bentuk yang sudah menjadi antara lagu dan iringannya (Muhammad Syafiq, 2003: 272).

Istilah seriosa pada awalnya merupakan cara untuk mengelompokkan gaya musik yang dibuat oleh RRI (Radio Republik Indonesia). Istilah tersebut muncul pada saat diadakan lomba bintang radio. Istilah tersebut hanya untuk memudahkan dalam pengelompokan jenis lagu yang dilombakan. Jenis lagu yang dilombakan adalah jenis keroncong dan hiburan. Untuk membedakan jenis hiburan antara lagu pop dan lagu yang serius, maka muncul istilah lagu seriosa sebagai nama untuk lagu yang serius. Lagu serius dalam konteks jenis lagu yang dibuat dengan teknik musikal dari Barat. Kemudian muncul istilah lomba jenis lagu keroncong, hiburan dan seriosa (Tedy Suthady, dalam wawancara tanggal 2 Agustus 2012).

\section{Kesimpulan}

Paham Nasionalisme di Eropa sudah mulai berkembang pada tahun 1830 dan sejak saat itu mulai menyebar ke seluruh dunia termasuk ke Indonesia. Nasionalisme Eropa membawa perubahan di berbagai bidang termasuk dalam bidang musik. Pada bidang musik muncul bentuk-bentuk musik yang baru, yang lebih mengutamakan karya musik yang berdasarkan musik rakyat atau bangsanya masing-masing.

Musik pada masa akhir abad ke-19 dan awal abad ke-20 adalah jaman yang mengalami banyak perubahan akibat dari gerakan nasionalisme di Eropa. Pada saat itu aliran musik romantik di Jerman dan Perancis mulai berakhir. Masa tersebut sekaligus menjadi transformasi dari gaya romantik menjadi suatu bentuk musik yang baru, khususnya terdapat di negara Jerman.

Pergerakan Nasional merupakan bagian dari Sejarah Nasional Indonesia pada abad ke-20 yang ditandai dengan munculnya nasionalisme di Indonesia. Munculnya organisasi-organisasi pergerakan nasional antara lain seperti Budi Utomo (1908), Pasundan (1914), Sarekat Sumatra (1918), Jong Java (1918), Jong Minahasa (1918), Sarekat Ambon (1920), Timorsch Verbond (1921), kaum Betawi (1923) dan lain sebagainya Organisasi-organisasi tersebut merupakan menjadi tempat pemuda bangsa untuk menyalurkan gagasan-gagasan nasionalisme.
Pengaruh musik Barat ke Indonesia terutama terhadap perkembangan musik nasional di Indonesia merupakan pengaruh musikal. Tangganada diatonis dari Barat bukan saja menciptakan perpaduan musik Barat dan musik Timur, tetapi justru tangganada inilah yang mendasari terciptanya musik nasional Indonesia.

Lied adalah komposisi untuk musik vokal di Jerman yang memiliki tiga buah bentuk yaitu bentuk lagu strophic, bentuk lagu through-composed dan song cycle. Penjelasan tentang lied yang berasal dari Jerman, art song atau sastra lagu adalah sebuah komposisi yang diperuntukkan bagi vokal solo dan iringan piano.

Lagu seriosa adalah lagu komposisi untuk musik vokal Indonesia, dan merupakan pengaruh musikal dari lied yang berasal dari Jerman. Lagu seriosa mulai berkembang di Indonesia pada tahun 1930-an yang dipelopori oleh C. Simanjutak. Istilah seriosa pada awalnya merupakan cara untuk mengelompokkan gaya musik yang dibuat oleh RRI (Radio Republik Indonesia). Istilah tersebut muncul pada saat diadakan lomba bintang radio. Istilah tersebut hanya untuk memudahkan dalam pengelompokan jenis lagu yang dilombakan. Pada lagu seriosa Indonesia tetap terdapat nuansa musik nusantara, budaya, historis dan nilai nasionalisme Indonesia. Hingga akhirnya lagu seriosa menjadi lagu khas Indonesia dan menjadi sebuah bentuk musik baru di Indonesia.

\section{Kepustakaan}

Departemen Pendidikan Nasional. 2004. Kamus Besar Bahasa Indonesia. Jakarta: Balai Pustaka.

Eryono, A., R. Sukandar, P. Herukusuma, dan Moh Noeh. 1985. Memoar Perjoangan Menegakkan Negara Proklamasi 17 agustus 1945, Yogyakarta : Yayasan Wiratama 45.

Fortune, Nigel, 1969, The New Harvard Dictionary of Music. London: The Belknap Press.

Hardjowirogo, Marbangun. 1983. Manusia Jawa. Jakarta: CV Haji Masagung.

Kamien, Roger. 1988. Music an Appreciation. New York: Mc Graw-Hill.

Kartodirdjo, Sartono. 1993. Pendekatan Ilmu Sosial dalam Metodologi Sejarah, Jakarta: PT Gramedia Pustaka Utama.

Kohn, Hans. 1984. Nasionalisme dan Arti Sejarahnya. Jakarta: Penerbit Erlangga. 
Martono, Sri. 1953. Kehidupan Seni Suara Tahun 1945-1952, Yogyakarta: Kementerian Penerangan Republik Indonesia.

Marwati Djoened Poesponegoro dan Nugroho Notosusanto. 1984. Sejarah Nasional Indonesia $V$. Jakarta: PN Balai Pustaka.

McNeill, Rhoderick J. 2003. Sejarah Musik 2. Jakarta: PT BPK Gunung Mulia.

Moleong, Lexy J. 2004. Metodologi Penelitian Kualitatif, Bandung: PT Remaja Rosdakarya.

Peake, Luise Eitel. 1984. "Song Cycle" dalam Stanley Sadie (ed) The New Grove Dictionary of Music and Musician. New York: Mac Millan Publisher Ltd.

Scholes, Percy A. 1978. The Oxford Companion to Music, London: Oxford University Press.
Soedarsono, R.M. 2001. Metodologi Seni Pertunjukkan dan Seni Rupa. Bandung: Masyarakat Seni Pertunjukan Indonesia.

Syafiq, Muhammad. 2003. Ensiklopedia Musik Klasik. Yogyakarta: Adicita Karya Nusa.

Tilmouth, Michael. 1984. "Strophic" dalam Stanley Sadie (ed). The New Grove Dictionary of Music and Musician. New York: Mac Millan Publisher Ltd.

\section{Informan}

Hj. Harmunah (74 tahun). Pengamat dan praktisi musik.

Teddy Sutadhy (70 tahun). Pengamat musik dan akademisi. 